\title{
PRECIPITATION AND TIMING OF FLOWERING IN GHOST ORCHIDS (EPIPOGIUM APHYLLUM SW.)
}

\author{
T. NAGY ${ }^{1}$, K. NótÁri ${ }^{2}$, A. TAkÁcs ${ }^{2,3}$, T. Malkócs ${ }^{2,3}$, J. TöKÖlyi ${ }^{4}$ and A. Molnár V. ${ }^{2 *}$ \\ ${ }^{1}$ Department of Plant Sciences and Biotechnology, Faculty of Georgikon, University of Pannonia \\ H-8360 Keszthely, Festetics u. 7, Hungary \\ ${ }^{2}$ Department of Botany, Faculty of Sciences, University of Debrecen \\ H-4032 Debrecen, Egyetem tér 1, Hungary; E-mail: *mva@science.unideb.hu \\ ${ }^{3}$ MTA-DE 'Lendület' Evolutionary Phylogenomics Research Group, University of Debrecen \\ H-4032 Debrecen, Egyetem tér 1, Hungary \\ ${ }^{4}$ MTA-DE Behavioural Ecology Research Group, University of Debrecen \\ H-4032 Debrecen, Egyetem tér 1, Hungary
}

(Received 17 November, 2017; Accepted 4 December, 2017)

The rare, fully mycoheterotrophic Ghost Orchid, Epipogium aphyllum is only visible during its short flowering and fruiting season, which lasts for a few weeks between May and October. Due to the apparent unpredictability of its flowering, decades may pass between subsequent observations at the same locality. The factors affecting timing of flowering in this enigmatic species remain largely unexplored. In Hungary, it is an extremely rare species: between 1924 and 2014 only 25 dated observations from 15 locations are known. Hungary is located on the edge of the species' distribution area where higher precipitation may occur only in higher regions of mountains. Hence, the spatial and temporal pattern of precipitation might limit the emergence of generative shoots. In this paper we compared rainfall patterns in relation with the Ghost Orchids' observations to multiannual precipitation averages. The year of flowering and the month preceding flowering (but not the year before flowering and the month of flowering) were characterised by significantly more rainfall than the multi-annual average precipitation. These results suggest that the appearance of the species in Hungary is precipitation-dependent.

Key words: herbarium, natural history collections, Orchidaceae, phenology, rainfall

\section{INTRODUCTION}

Epipogium aphyllum Sw. is a rare Eurasian achlorophyllous, mycoheterotrophic forest orchid (Hultén and Fries 1986; Roy et al. 2009). The species is native to the temperate deciduous and evergreen forests of Eurasia, with a distribution area spreading from Great Britain through Scandinavia to the Kamchatka Peninsula (Taylor and Roberts 2011). The occurrence of the species is considered rare (Delforge 2005), despite covering a wide area and despite the fact that it has been described in 56 countries to date (Govaerts et al. 2017). Due to its rarity, its biology is poorly known (Roy et al. 2009). The species is often protected, in many countries it is on the red list. According to the IUCN Red List's criteria it is categorised as near threathened ("NT") in Slova- 
kia (Turis et al. 2014), vulnerable ("VU") in Bulgaria (Petrova and Vladimirov 2009), endangered ("EN") in Murmansk Region of Russia (Blinova and Uotila 2011) or critically endangered ("CR") in Austria (Tasenkevich 2003), the Czech Republic (Grulich 2012), Ukraine (Tasenkevich 2003), Serbia (Tomović et al. 2007), England (Stroh et al. 2014) and Hungary (Király 2007).

Epipogium aphyllum is named Ghost Orchid because of its irregular, unpredictable flowering (Taylor and Roberts 2011). The temporal and spatial emergence of the species is largely unpredictable, and can happen any time from late May until early October. On the British Isles it was usually recorded from late July until the end of August (Taylor and Roberts 2011). Often, decades pass between successive observations on the same locality. Söyrinki (1987) encountered the species only after 36 years on the same site. In Finland and Sweden there are floristically well-described areas where it turned up unexpectedly. As some of these occurrences were later not confirmed, these populations are considered temporary (Söyrinki 1987). Meanwhile, in Sweden there are habitats, where it has been flowering for 30 consecutive years. Its emergence in Hungary is also a rarity, counting only 25 observations during the last hundred years. Until 1998 it has never been observed twice at the same site in the country.

The reason for its fitful emergence might be that environmental conditions are not ideal every year for flowering. According to some authors, Epipogium aphyllum is more often observed during summers with more precipitation (Dahlskog 1980, Summerhayes 1951). On the other hand, according to Söyrinki's (1987) study in Finland, there is no significant relationship between flowering and precipitation. Differences in environmental variables, for example in the topography of habitats, temperature, etc. could have led to the above results.

Our goal in this study was to evaluate whether observations of this species are associated with different rainfall patterns. Our hypotheses were tested on Hungarian populations found on the margin of the species' distribution area.

We tested whether emergence of Epipogium aphyllum is influenced by the amount of precipitation in the following four periods:

1 . in the year preceding flowering;

2. in the year of flowering;

3 . in the month preceding flowering;

4. in the month of flowering.

\section{MATERIALS AND METHODS}

Occurrence data in Hungary are based on literature (11), herbaria (BP: 3, Zirc: 1) and personal communications (10) (Table 1). Three out of the 4 herbarium data were published before. Some of the observations are dated to 
Table 1

Observations of Epipogium aphyllum in Hungary between 1924 and 2014, related meteorological stations and precipitation data used in this study. Personal communications are marked with asterisks

\begin{tabular}{|c|c|c|c|c|}
\hline Date & Locality & Collector or informant & Source & Met. station \\
\hline 06.07.1924 & Csesznek & S. Polgár & Polgár (1935), Herb. BP & Bakonybél \\
\hline 12.07.1953 & Bakonyszücs & L. Bánó & Kovács (1957), Herb. BP & Bakonybél \\
\hline 07.07.1954 & Dömös & É. Kovács & Kovács (1957), Herb. BP & Dobogókő \\
\hline 15.07.1955 & Fenyőfő & P. Tallós & Tallós (1959) & Ugod \\
\hline 15.09.1975 & Vékény & P. Millner & Horvát (1976) & Kárász \\
\hline 25.06.1975 & Ajka & I. Galambos & Herb. Zirc & Úrkút \\
\hline 18.07.1992 & Pécsvárad & S. Farkas & $\begin{array}{l}\text { Molnár and Farkas } \\
\text { (1996) }\end{array}$ & Pécsvárad \\
\hline 01.10 .1994 & Bozsok & K. Robatsch & Robatsch (1995) & Kőszeg \\
\hline 14.07.1996 & Bakonybél & G. Király and A. Rigó & $\begin{array}{l}\text { Bölöni and Király } \\
\text { (1997) }\end{array}$ & Bakonybél \\
\hline 17.07.1996 & Bakonybél & $\begin{array}{l}\text { N. Antal, N. Povics, } \\
\text { and D. Nagy }\end{array}$ & $\begin{array}{l}\text { Bölöni and Király } \\
\text { (1997) }\end{array}$ & Bakonybél \\
\hline 25.07.1998 & Bozsok & H. Presser & H. Presser* & Kőszeg \\
\hline 01.07.2001 & $\begin{array}{l}\text { Hetvehely- } \\
\text { Kán }\end{array}$ & I. Hődör & Hődör (2011) & Bakonya \\
\hline 20.06.2008 & Bükkzsérc & $\begin{array}{l}\text { M. Sulyok and J. } \\
\text { Sulyok }\end{array}$ & $\begin{array}{l}\text { Sulyok and Sulyok } \\
\text { (2010) }\end{array}$ & Bükkzsérc \\
\hline 05.07.2009 & Pécs & $\begin{array}{l}\text { D. Kovács and T. } \\
\text { Wirth }\end{array}$ & $\begin{array}{l}\text { Kovács and Wirth } \\
\text { (2009) }\end{array}$ & Pécs \\
\hline 30.06 .2009 & Bükkzsérc & $\begin{array}{l}\text { M. Sulyok and J. } \\
\text { Sulyok }\end{array}$ & $\begin{array}{l}\text { Sulyok and Sulyok } \\
\text { (2010) }\end{array}$ & Bükkzsérc \\
\hline 10.08 .2010 & Pécsvárad & A. Molnár V. & A. Molnár V.* & Pécsvárad \\
\hline 13.07.2010 & Pécsvárad & I. Zs. Tóth & Tóth (2011) & Pécsvárad \\
\hline 20.08 .2010 & Ajka & $\begin{array}{l}\text { A. Molnár V., A. Mé- } \\
\text { száros and P. Simon }\end{array}$ & $\begin{array}{l}\text { A. Molnár V., A. Mé- } \\
\text { száros and P. Simon* }\end{array}$ & Úrkút \\
\hline 17.06.2011 & Pétervására & $\begin{array}{l}\text { J. Sulyok and A. B. } \\
\text { Lukács }\end{array}$ & $\begin{array}{l}\text { J. Sulyok and A. B. } \\
\text { Lukács* }\end{array}$ & Pétervására \\
\hline 30.06 .2011 & Bükkzsérc & J. Sulyok & J. Sulyok* & Bükkzsérc \\
\hline 05.07.2013 & Bozsok & $\begin{array}{l}\text { S. Makádi and M. } \\
\text { Csábi }\end{array}$ & S. Makádi, M. Csábi* & Kőszeg \\
\hline 06.07.2013 & Bükkzsérc & J. Sulyok and M. Csábi & J. Sulyok, M. Csábi* & Bükkzsérc \\
\hline 14.06.2014 & Bozsok & $\begin{array}{l}\text { S. Makádi and M. } \\
\text { Csábi }\end{array}$ & S. Makádi, M. Csábi* & Kőszeg \\
\hline 23.09.2014 & Bükkösd & A. Kiticsics & A. Kiticsics* & Bakonya \\
\hline 01.08.2014 & Kemence & B. Vida & B. Vida* & Kemence \\
\hline
\end{tabular}


the day, while in some cases flowering time was given as a period of time. In these cases we used the first day of the period during data analysis. Precipitation data used in our study were provided by the Hungarian Meteorological Service (Budapest). We obtained precipitation data from periods potentially influencing flowering from the nearest weather stations to each observation site between 1923 and 2014. Also, we acquired average annual precipitation data based on a recent 30 years long period (1981-2010).

To find out whether periods preceding observations of E. aphyllum are unusual in terms of precipitation, we first calculated the difference between rainfall in the four periods related to flowering and the long-term average of these periods at the same sites. We then tested whether these precipitation differences follow a normal distribution, using Shapiro-Wilk's test of normality. Since none of these variables showed a significant deviation from a normal distribution (year preceding flowering: $p=0.487$; year of flowering: $p=0.391$; month preceding flowering: $\mathrm{p}=0.399$; month of flowering: $\mathrm{p}=0.541$ ) (Fig. 1 ), we employed one-sample $t$-tests on the statistical null hypothesis that the mean of the temperature differences is $0(\mu=0$; i.e. precipitation in or preceding the year/month of flowering does not differ significantly from the longterm average).
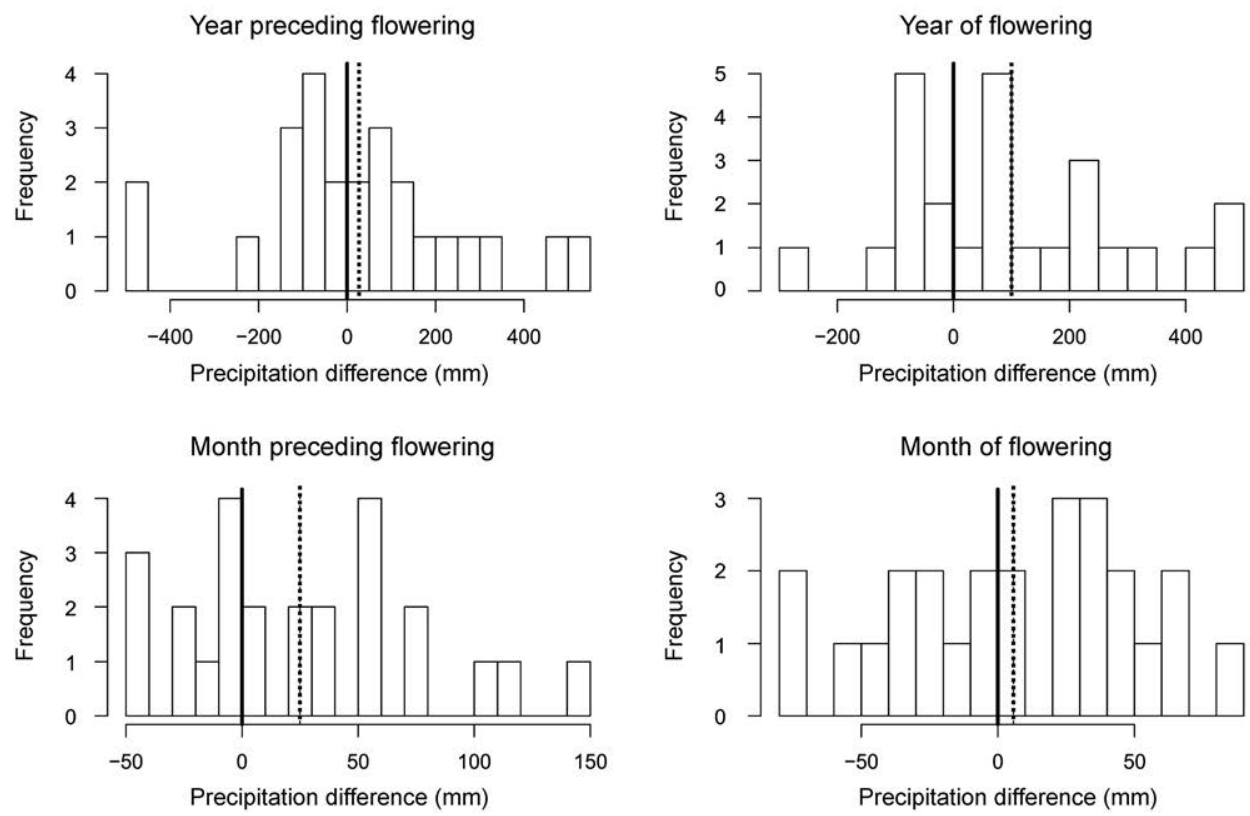

Fig. 1. Distribution of difference between precipitation in the four periods before flowering and the multiannual average of these periods at the same sites. The dotted line marks the mean, the thick continuous line marks zero 


\section{RESULTS AND DISCUSSION}

The species was observed in Hungary 25 times at 15 locations (Fig. 2). Dated occurrences of the species are known from 16 years over a 90-year period (1924-2014). Mean \pm SD number of observations on a given locality was $1.56 \pm 1.09$. In the majority $(75 \%)$ of the localities it was observed only once.

According to our data, flowering happens between June and October (Fig. 3). The earliest observation was on the 14th of June, while the latest was on the 10th October. In more than half of all cases, flowering (56\%) was observed in July (Fig. 3). Average annual precipitation in Hungary is between 500 and $750 \mathrm{~mm}$ (Justyák 2002), but this value was $708 \pm 80 \mathrm{~mm}$ at meteorological stations adjacent to observation sites of E. aphyllum and $808 \pm 212 \mathrm{~mm}$ in the years of observations. Occurrences of the species in Hungary are limited to the regions of Hungary characterised mostly by over $650 \mathrm{~mm}$ annual precipitation (Fig. 2).

The amount of precipitation was significantly higher in the year of flowering and the month before flowering than the multiannual average (Table 2). There was no significant difference between precipitation in the year prior to flowering, the month of flowering and the average annual precipitation (Table 2).

Based on these findings the precipitation during the year of flowering and the month preceding flowering has a key role in the induction of emergence and flowering of Epipogium aphyllum. Precipitation-dependence of this species may be related to its achlorophyllous mycoheterotrophic nature, be-

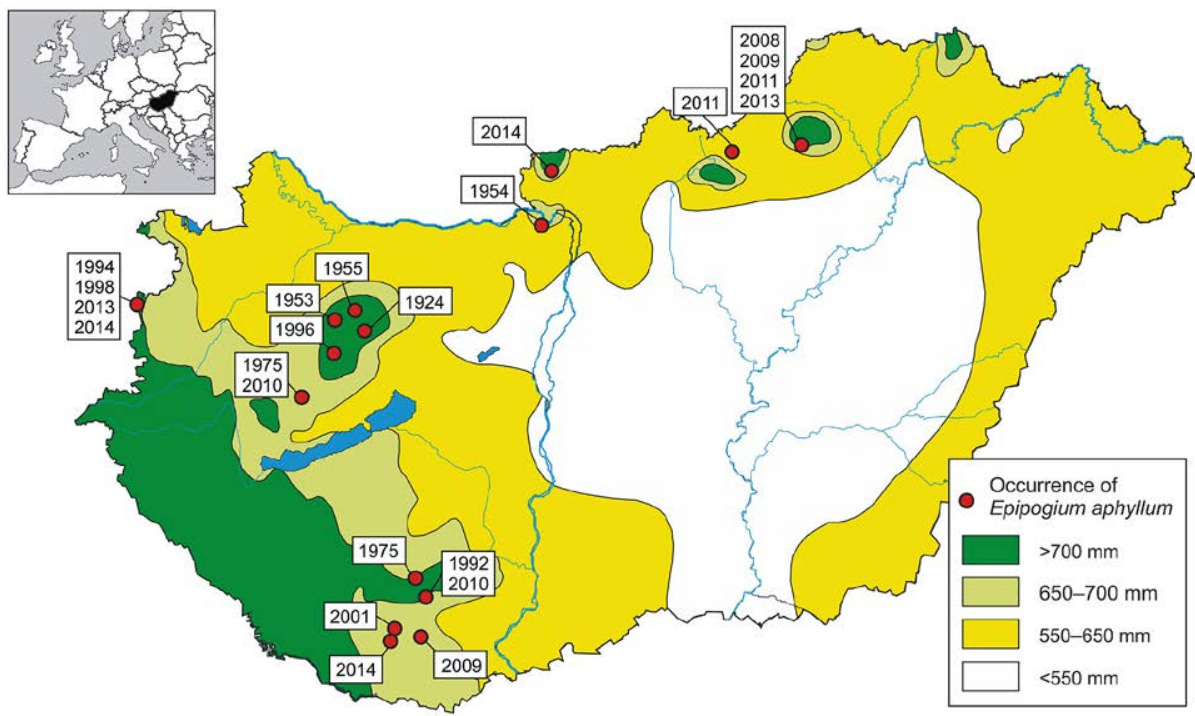

Fig. 2. Occurrences of Epipogium aphyllum in Hungary (marked by red dots and year of detection) with the map of average annual precipitation based on data between 1971 and 2000 
Table 2

Comparison of amount of precipitation of different periods of preceding flowering with multiannual average of same periods. P-values are from one-sample $t$-tests on the null hypothesis that deviation of rainfall amount preceding E. aphyllum observations from the multiannual average is 0

\begin{tabular}{lccc}
\hline Periods & $\begin{array}{c}\text { Mean } \pm \text { SD of cumulative precipita- } \\
\text { tion related to observation periods } \\
\text { of E. aphyllum }(\mathrm{mm})\end{array}$ & $\begin{array}{c}\text { Multi-annual } \\
\text { average }(\mathrm{mm})\end{array}$ & p-value \\
\hline $\begin{array}{l}\text { Year preceding } \\
\text { flowering }\end{array}$ & $735.0 \pm 211.3$ & $707.9 \pm 81.5$ & 0.574 \\
$\begin{array}{l}\text { Year of flowering } \\
\text { Month preceding }\end{array}$ & $808.1 \pm 212.1$ & $707.9 \pm 81.5$ & 0.013 \\
$\begin{array}{l}\text { flowering } \\
\text { Month of flowering }\end{array}$ & $105.7 \pm 50.9$ & $80.8 \pm 12.5$ & 0.023 \\
\hline
\end{tabular}

cause nutritionally it is entirely dependent on its endomycorrhizal fungal symbionts (Inocybe spp.) (Liebel and Gebauer 2011, Roy et al. 2009).

Observation of the species is difficult, as its inconspicuous shoots are observable for only a short period (approx. 2 weeks), and flowering can take place during a 4-month period. Monitoring populations is only possible with regular and frequent surveys. Research of the past years suggests that populations with low number of specimens and with such unpredictable flowering are observable in consecutive years.

According to our findings, years with higher than average precipitation are the most suitable for surveying known populations or finding new ones, especially during a period following summer months with higher than average precipitation.

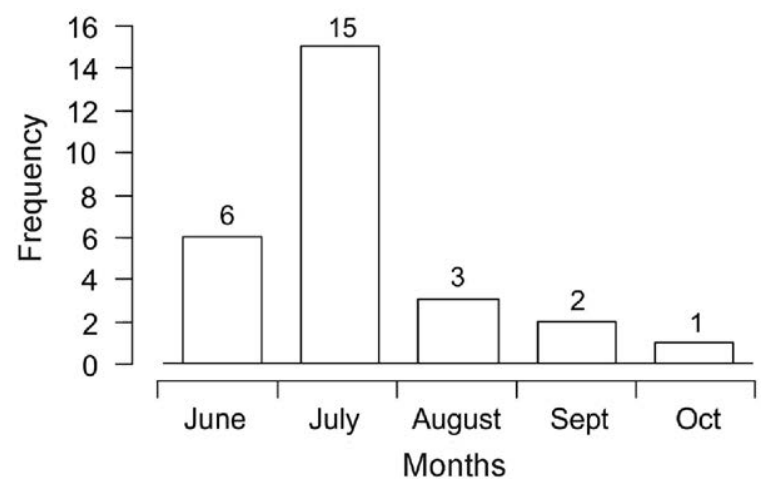

Fig. 3. Phenology of Epipogium aphyllum in Hungary, based on 25 observations 
Acknowledgements - The authors are grateful to András Balázs Lukács, András Mészáros, Anikó Kiticsics, Balázs Vida, Helmut Presser, József Sulyok, Miklós Csábi, Miklós Óvári, Pál Simon, Sándor Makádi for their kind assistance. We would like to thank the Hungarian Meteorological Service (OMSZ) for the provision of precipitation data. This research was supported by the OTKA K108992 grant. J. Tökölyi was supported by the János Bolyai Research Scholarship of the Hungarian Academy of Sciences. Work of A. Takács and J. Tökölyi was supported by the ÚNKP-17-4 New National Excellence Program of the Ministry of Human Capacities. The publication is supported by the EFOP-3.6.3-VEKOP-16-2017-00008 project. The project is co-financed by the European Union and the European Social Fund.

\section{REFERENCES}

Blinova, I. V. and Uotila, P. (2011): Chamorchis alpina and Epipactis helleborine in the Murmansk Region, Russia, and assessments of the orchids in the region using the IUCN Red List Categories. - Mem. Soc. Fauna Flora Fenn. 87: 21-28.

Bölöni, J. and Király, G. (1997): A bajuszvirág (Epipogium aphyllum (F. W. Schmidt) Sw.) két új előfordulása a Bakonyban. (Two new occurrences of Epipogium aphyllum (Schm.) Sw. in Bakony Mountain). - Kitaibelia 2: 20-21.

Dahlskog, S. (1980): Skogsfrun, Epipogium aphyllum, i Nordnorge och Nordsverige. (Epipogium aphyllum in Northern Scandinavia). - Svensk Bot. Tidskr. 74: 145-152. [In Swedish]

Delforge, P. (2005): Orchids of Europe, North Africa and the Middle East. - A\&C Black, London, $640 \mathrm{pp}$.

Govaerts, R. U. C., Barker, C. and Govaerts, L. R. (2017): World checklist of selected plant families. - The Board of Trustees of the Royal Botanic Gardens, Kew. http://www.kew. org/wcsp/ [accessed 20.09.2017]

Grulich, V. (2012): Red list of vascular plants of the Czech Republic. 3rd ed. - Preslia 84: 631-645.

Hődör, I. (2001): Bajuszvirág (Epipogium aphyllum (Schm.) Sw.) a Zselicben. (Epipogium aphyllum (Schm.) Sw. in Zselic region). - Kitaibelia 6(2): 403.

Horvát, A. O. (1976): Pótlások és kiegészítések a "Mecsek hegység és déli síkjának növényzete" ismereteihez (1942-1975) III. (Additions and to the knowledge of the flora Mecsek and its southern plain). - Dunántúli Dolgozatok 10: 23-46.

Hultén, E. and Fries, M. (1986): Atlas of North European vascular plants (North of the Tropic of Cancer). Vols I-III. - Koeltz Scientific Books, Koenigstein, Germany.

Jackowiak, B., Celka, Z., Chmiel, J., Latowski, K. and Żukowski, W. (2007): Red list of vascular flora of Wielkopolska (Poland). - Biodiv. Res. Conserv. 5(8): 95-127.

Justyák, J. (2002): Magyarország éghajlata. - Kossuth Egyetemi Kiadó, Debrecen, 118 pp. [In Hungarian]

Király, G. (ed.) (2007): A magyarországi edényes flóra veszélyeztetett fajai. (Red list of the vascular flora of Hungary). - Private edition, Sopron, 73 pp. [In Hungarian with a summary in English]

Kovács, D. and Wirth, T. (2009): A bajuszvirág (Epipogium aphyllum (F. W. Schmidt) Sw.) és néhány Epipactis-faj előfordulása Pécsett. (Occurrence of Epipogium aphyllum 
(F. W. Schmidt) Sw. and some Epipactis species in Mecsek Mountains). - Kitaibelia 14(1): 104-106.

Kovács, É. (1957): Az Epipogium aphyllum (Schm.) Sw. a Pilisben. (Epipogium aphyllum (Schm.) Sw. in Pilis Mountains). - Bot. Közlem. 47: 114.

Liebel, H. T. and Gebauer, G. (2011): Stable isotope signatures confirm carbon and nitrogen gain through ectomycorrhizas in the ghost orchid Epipogium aphyllum Swartz. Plant Biol. 13(2): 270-275. https://doi.org/10.1111/j.1438-8677.2010.00369.x

Molnár, A. and Farkas, S. (1996): Az Epipogium aphyllum (Schm.) Sw. új előfordulása a Mecsekben. (New occurrence of Epipogium aphyllum (Schm.) Sw. in Mecsek Mountains). - A Janus Pannonius Múz. Évk. 40: 9-12.

Petrova, A. and Vladimirov, V. (eds) (2009): Red list of Bulgarian vascular plants. - Phytol. Balcan. 15: 63-94.

Polgár, S. (1935): A Cuha-völgy növényzeti viszonyai. (Vegetation of Cuha-valley). - Györi Szemle 5: 149-160.

Robatsch, K. (1995): Beiträge zur Kenntnis der europäischen Epipactis-Arten (Orchideceae) und zur Evolution der Autogamie bei europäischen und asiatischen Gattungen der Neottioideae. - J. Eur. Orchideen 27(1): 125-177.

Roy, M., Yagame, T., Yamato, M., Iwase, K., Heinz, C., Faccio, A., Bonfante, P. and Selosse, M. A. (2009): Ectomycorrhizal Inocybe species associate with the mycoheterotrophic orchid Epipogium aphyllum but not its asexual propagules. - Ann. Bot. 104(3): 595610. https://doi.org/10.1093/aob/mcn269

Söyrinki, N. (1987): On the periodicity in the flowering of Epipogium aphyllum (Orchidaceae). - Mem. Soc. Fauna Flora Fenn. 63: 63-72.

Stroh, P. A., Leach, S. J., August, T. A., Walker, K. J., Pearman, D. A., Rumsey, F. J., Harrower, C. A., Fay, M. F., Martin, J. P., Pankhurst, T., Preston, C. D. and Taylor, I. (2014): A vascular plant red list for England. - Botanical Society of Britain and Ireland, Bristol.

Sulyok, M. and Sulyok, J. (2010): Az Epipogium aphyllum (F. W. Schmidt) Sw. előfordulása a Bükk hegységben. (Epipogium aphyllum (Schm.) Sw. in Bükk Mountains). - Kitaibelia 16(1-2): 97-98.

Summerhayes, V. S. (1951): Wild orchids of Britain with a key to the species. - Collins, London, 366 pp.

Tallós, P. (1959): Növényföldrajzi és florisztikai adatok a Dunántúlról. (Phytogeographical and floristic data from Transdanubia). - Bot. Közlem. 48: 77-80.

Tasenkevich, L. (2003): Vascular plants. - In: Witkowski, Z. J., Król, W. and Solarz, W. (eds): Carpathian list of endangered species. WWF and Institute of Nature Conservation, Polish Academy of Sciences, Vienna-Kraków, pp. 6-19.

Taylor, L. and Roberts, D. L. (2011): Biological flora of the British Isles: Epipogium aphyllum Sw. - J. Ecol. 99(3): 878-890.

Tomović, G., Vukojičić, S., Niketić, M. and Lakušić, D. (2007): New chorological data on some threatened and rare plants in Serbia. - Arch. Biol. Sci. (Belgrade) 59(1): 63-73. https://doi.org/10.2298/abs0701063t

Tóth, I. Zs. (2011): Az Epipogium aphyllum új lelőhelye a Mecsekben. (New locality of Epipogium aphyllum in Mecsek Mountains). - Kitaibelia 15(1-2): 180.

Turis, P., Kliment, J., Feráková, V., Dítě, D., Eliáš, P., Hrivnák, R., Koštál, L., Šuvada, R., Mráz, P. and Bernátová, D. (2014): Red list of vascular plants of the Carpathian part of Slovakia. - Thaiszia 24(1): 35-87. 